\title{
Respiratory Tract Problems among Wood Furniture Manufacturing Factory Workers in the Northeast of Thailand \\ Soongkhang I, ${ }^{1}$ Laohasiriwong $\mathrm{W}^{2}$
}

${ }^{1}$ Dr. P.H. Program in Public Health

Faculty of Public Health, Khon Kaen University, Khon Kaen 40002, Thailand

${ }^{2}$ Faculty of Public Health

Research and Training Center for Enhancing Quality of Life of Working-Age People,

Khon Kaen University

123 Moo 16 Mittapap Road, Nai-Mueang, Mueang District, Khon Kaen 40002, Thailand

\section{Corresponding Author}

Wongsa Laohasiriwong

Faculty of Public Health

Research and Training Center for Enhancing Quality of Life of Working-Age People,

Khon Kaen University

123 Moo 16 Mittapap Road, Nai-Mueang, Mueang District, Khon Kaen 40002, Thailand

E-mail: drwongsa@gmail.com

\section{Citation}

Soongkhang I, Laohasiriwong W. Respiratory Tract Problems among Wood Furniture Manufacturing Factory Workers in the Northeast of Thailand. Kathmandu Univ Med J 2015;50(2):125-9.

\section{ABSTRACT}

\section{Background}

Wood furniture manufacturing factory workers are at high risk of exposure to wood dust in wood working processes. Wood dust exposure could cause respiratory symptoms, such as reduce lung function, chronic bronchitis, and asthma. The Northeast region of Thailand has many wood furniture manufacturing factories. However, limited studies were carried out to explore the effect of wood dust exposure on workers.

\section{Objective}

This study aimed to assess the respiratory symptoms and determine factors associated with these symptoms among wood furniture manufacturing factory workers.

\section{Method}

This cross-sectional analytical research used a multistage random sampling to select 511 workers from three provinces in the Northeast of Thailand. The data was collected using a structured questionnaire interview. The content validity of questionnaire was tested by 3 experts and had a Cronbach's alpha coefficient of 0.82 . Data were analyzed using descriptive statistics and multiple logistic regressions.

\section{Result}

The result indicated that $29.94 \%$ of these workers had respiratory symptoms, including coughing(18.79\%), nasal secretion (15.66\%), and stuffy nose (15.07\%). Factors that were significantly associated with respiratory symptoms ( $p$-value $<0.05$ ) were (a) not always wearing mask (adjusted $\mathrm{OR}=2.26 ; 95 \% \mathrm{Cl}=1.37-3.72$ ), (b) low to medium level of knowledge on dust prevention (adjusted $\mathrm{OR}=1.83 ; 95 \% \mathrm{Cl}=1.23$ 2.73) and (c) contacted softwood dust (adjusted $\mathrm{OR}=1.97 ; 95 \% \mathrm{Cl}=1.06-3.64$ ).

\section{Conclusion}

About $30 \%$ of wood furniture manufacturing factory workers had respiratory symptoms with related to both personal preventive behaviors and their working environments. Therefore, the raising awareness for using personal protective equipment during work will help them to prevent from various respiratory track problems.

\section{KEY WORDS}

Northeast of Thailand, respirable dust, respiratory symptoms, wood dust, wood furniture manufacturing. 


\section{INTRODUCTION}

Respiratory system is the first tract that was harmed by toxic dust. ${ }^{1}$ Prolong occupational exposure to the toxic dust could irritate the respiratory system, damage the lung tissues, create fibrotic tissues and impair lung function (Occupational respiratory diseases) such as asthma, asbestosis, silicosis etc. ${ }^{2-5}$ In Thailand, occupational respiratory diseases have been increasing each year. ${ }^{6}$ Wood processing from furniture factory caused wood dust and other health hazards including chemicals, bacteria and mold. The dust are divided into 2 groups according to their size, the first is called "Total dust" which particle are larger than 10 micron (PM10), mainly are soft dust that could enter the upper respiratory tract and excreted by coughing or sneezing, " another type is "Respirable dust" that has particle smaller than 10 micron $(P M<10)$, mainly from hardwood which could enter the lower respiratory tract to alveoli, the disposition of these particles is limited and tends to accumulate in the lung tissues that leads to chronic bronchitis and impairs lung function. ${ }^{8,9}$ Scientific evidences suggested that abnormalities of respiratory system were directly correlated with the type of wood, concentration of wood dust, duration of dust exposure, types of chemical, individual sensitivity, use of personal protective equipments and air ventilation system. ${ }^{10}$ Lack of knowledge and incorrect attitude on preventive measures of wood manufacture workers also associated with abnormality of respiratory symptoms such as wood dust allergy which was the leading cause of asthma related to their works. ${ }^{11}$ The study of these issues in Thailand were limited, this study therefore aimed to assess the respiratory symptoms and determine factors associated with these symptoms of wood furniture manufacturing factory workers which will be schemed for the policy proposed to reduce health risk of workers and improve the working environment for better health of the workers.

\section{METHODS}

Recruitment of Subjects: This cross sectional analytical study was conducted among wood furniture manufacturing factory workers in the Northeast of Thailand. The required sample size was estimated using a formula for multiple logistic regressions to identify relationships between multiple independent variables and a dichotomous dependent variable. ${ }^{12}$ Multistage random sampling was utilized to select 511 workers from three provinces (NongKhai, Nakhon Ratchasima, Loei) (fig. 1).

The inclusion criteria for participants were that they were 18-59 years old, working in wood furniture manufacturing factory for $>6$ months, could verbally communicated with the researchers, not pregnant, not being prohibited to use spirometer. Data were collected between November 20, 2012 to February 20, 2013.

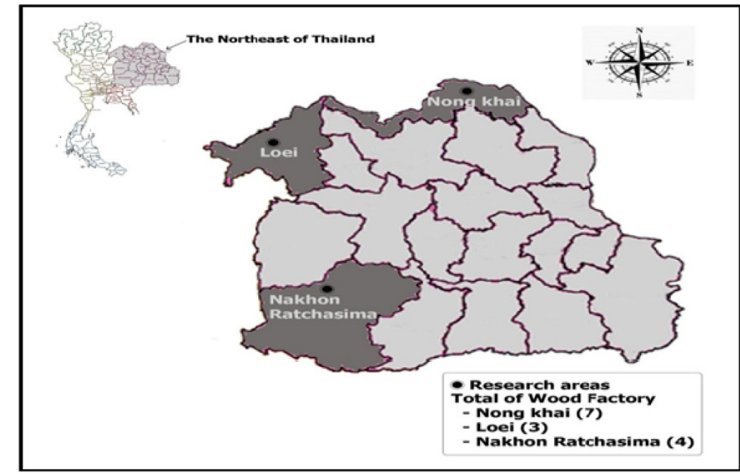

Figure 1. Map of the 3 provinces studied in the Northeast of Thailand.

Research Instruments: The study used a structured questionnaires consisted of 5 parts including (a) individual characteristics and socioeconomics (b) knowledge on wood dust prevention (c) attitude wood dust prevention (d) preventive behaviors during working and (e) the questions related to respiratory symptoms that were adapted from "The society of thoracic diseases of America and Department of Health in Thailand" questionnaire that was modified from the standard version of the American thoracic society division of lung disease questionnaire (ATS-DLD 1978) which considered to be highly reliable, ${ }^{13}$ and have been documented for the field test and widely used in many survey research. ${ }^{14}$ Three experts inspected and commented on the draft questionnaire, then revisions were made to improve its validity. This tool was also pretested among 30 workers in wood furniture manufacturing factories in Khon Kaen province. Reliability was assessed using Cronbach's alpha, yielding a score of 0.82 , which was judged acceptable.

Data Analysis: After data collection, the data were validated, coded and analyzed using the statistical application package STATA version 12. Descriptive statistics were used to examine the characteristics of workers and the prevalence of respiratory symptoms. Associations between independent variables and respiratory symptoms were analyzed using multiple logistic regression analysis to determine the adjusted odds ratio with a $95 \%$ confidence interval.

Research Ethics: This study was approved by the ethical committees of research in human, Khon Kaen University (reference no. HE 552153). The research objectives and the right of participants were clearly explained to subjects and the consent form was signed before collecting the data.

\section{RESULTS}

\section{Individual characteristics and wood dust exposure history of the study sample:}

About half of study subjects were male $(50.50 \%)$ with an average aged of $37.73 \pm 9.79$ years old, most of them finished primary education (63.99\%). Almost all had never worked 
in factory involved with dust $(96.08 \%)$. However $29.75 \%$ were current smokers. Half of study subjects worked in an operation division (dust involved), $40.31 \%$ has been working in the wood factory for more than 5 years. The average working hour was $8.00 \pm 0.66$ a day, $5.78 \pm 1.18$ days a week. Approximately $73.58 \%$ self-reported of exposed with hardwood dust, see (Table 1).

Table 1. Characteristics of Subjects. $(n=511)$

\begin{tabular}{|lll|}
\hline Characteristics & Number & $\%$ \\
\hline Gender: Male & 258 & 50.50 \\
\hline Age (years) & & \\
\hline$<20$ & 24 & 4.70 \\
\hline $20-30$ & 109 & 21.33 \\
\hline $31-40$ & 148 & 28.96 \\
\hline $41-50$ & 188 & 36.79 \\
\hline $51-59$ & 42 & 8.22 \\
\hline
\end{tabular}

Mean S.D. = $37.739 .79 \mathrm{yrs}$,

Median $(\min , \max )=39(18,59)$ yrs

\begin{tabular}{lll}
\hline Education: Finished primary education & 327 & 63.99 \\
\hline Smoking & & \\
\hline Never & 323 & 63.21 \\
\hline Ever, but current have stopped & 36 & 7.05 \\
\hline Current smokers & 152 & 29.75 \\
\hline Worked in factory involved with dust: & 491 & 96.08
\end{tabular}

Never

Duration of experience in working in the wood factory (years)

Mean S.D. = $37.739 .79 \mathrm{yrs}$,

Median $(\min , \max )=39(18,59)$ yrs

Average working hour per day

Mean S.D. $=8.00 \pm 0.66 \mathrm{hrs}$

Median $(\min , \max )=8(3,12) \mathrm{hrs}$

Average working day per week

Mean S.D. $=5.78 \pm 1.18$ day,

Median $(\min , \max )=6(1,7)$ day

\section{Wood dust exposure}

Exposed with soft wood dust

Exposed with solid wood dust

$\begin{array}{ll}436 & 85.32 \\ 376 & 73.58\end{array}$

Majority of the workers had high level of knowledge related wood dust prevention (52.84 \%) which the average scores of $7.49 \pm 1.41$ (total scores $=10$ ), $54.99 \%$ had good level of attitude on wood dust prevention with the average scores of $39.67 \pm 5.78$ (total score $=50$ ), and $54.01 \%$ had middle level of wood dust preventive behaviors with the average scores of $25.36 \pm 6.27$ (total score $=40$ ) (fig. 2 ).

\section{Respiratory symptoms of workers in wood furniture factory:}

29.94\% of wooden furniture factory workers ever had at least one respiratory problem. Respiratory symptoms were coughing (18.79\%), followed by having sputum, stuffy nose, breathless, and wheezing (15.66\%, 15.07\%, 7.83\% and $5.09 \%$, respectively) as shown in fig. 3 .

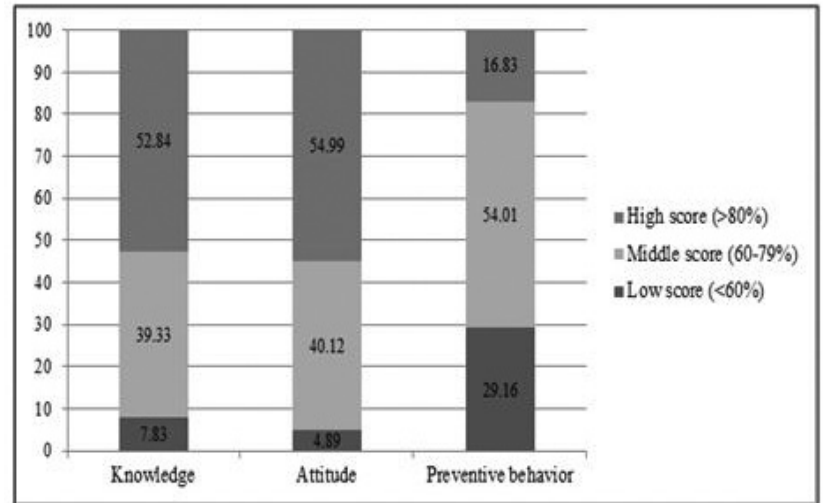

Figure 2. Knowledge, attitude, and dust preventive behavior of workers in wooden furniture factory.

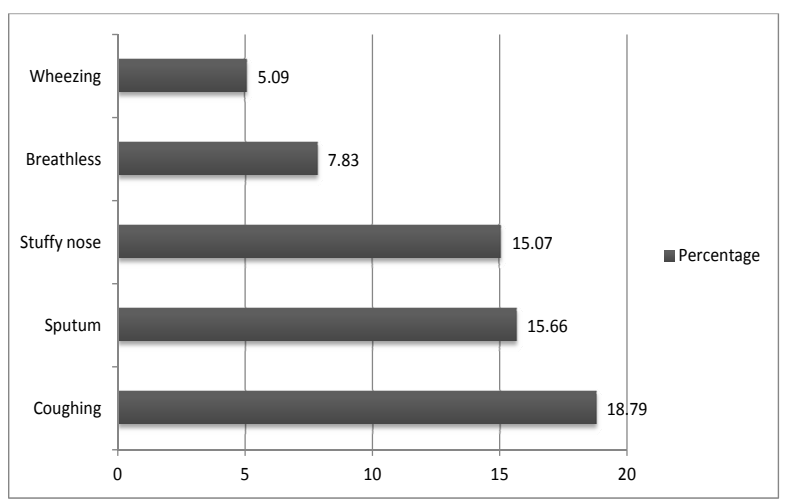

Figure 3. Prevalence with respiratory symptoms of workers in wooden furniture factory .

Table 2. The relationship between factors Associated with respiratory symptoms of workers in wood furniture factory (Binary correlation) $(n=511)$

\begin{tabular}{|c|c|c|c|c|c|}
\hline Factors & $\mathbf{N}$ & $\begin{array}{l}\text { Respiratory } \\
\text { symptoms (\%) }\end{array}$ & OR & $95 \% \mathrm{Cl}$ & $\begin{array}{l}p- \\
\text { value }\end{array}$ \\
\hline \multicolumn{6}{|c|}{ Wearing mask while working } \\
\hline Always & 427 & 27.40 & 1 & 1 & 0.005 \\
\hline Not always & 84 & 42.86 & 1.98 & $\begin{array}{l}1.22 \text { to } \\
3.21\end{array}$ & \\
\hline \multicolumn{6}{|l|}{ Softwood exposure } \\
\hline No contact & 75 & 20.00 & 1 & 1 & 0.044 \\
\hline Contact & 436 & 31.65 & 1.85 & $\begin{array}{l}1.02 \text { to } \\
3.38\end{array}$ & \\
\hline \multicolumn{6}{|l|}{ Smoking } \\
\hline No & 468 & 28.42 & 1 & 1 & \\
\hline Yes & 43 & 46.51 & 2.19 & $\begin{array}{l}1.16 \text { to } \\
4.12\end{array}$ & 0.015 \\
\hline \multicolumn{6}{|c|}{ Air vacuum in factory } \\
\hline Continuously & 415 & 27.47 & 1 & 1 & \\
\hline Not continuously & 96 & 40.63 & 1.80 & $\begin{array}{l}1.13 \text { to } \\
2.86\end{array}$ & 0.012 \\
\hline \multicolumn{6}{|c|}{ Knowledge on dust prevention } \\
\hline High level & 241 & 24.07 & 1 & 1 & 0.006 \\
\hline $\begin{array}{l}\text { Low to medium } \\
\text { level }\end{array}$ & 270 & 35.19 & 1.71 & $\begin{array}{l}1.16 \text { to } \\
2.52\end{array}$ & \\
\hline
\end{tabular}


Factors associated with respiratory symptoms of workers in wooden furniture factory:

Bivariate analysis was showed that some factors were statistically significant associated with respiratory symptoms. Factors with $\mathrm{p}$-value $\leq 0.25$ in the bivariate analysis including were selected as variables for the multivariate modeling process, and the results are given in Table 2.

Multivariate analysis using multiple logistic regression analysis indicated Factors that were significantly associated with respiratory symptoms ( $p$-value $<0.05$ ) were 1 ) not wearing mask (adjusted $\mathrm{OR}=2.26 ; 95 \% \mathrm{Cl}=1.37$ to 3.72 ; p-value $=0.001)$ 2) lower level of knowledge on dust prevention (adjusted $\mathrm{OR}=1.83 ; 95 \% \mathrm{Cl}=1.23$ to 2.73 ; p-value $=0.003)$, and 3 ) contacted softwood dust (adjusted $\mathrm{OR}=1.97 ; 95 \% \mathrm{Cl}=1.06$ to $3.64 ; \mathrm{p}$-value $=0.030$ ) (Table 3 ).

Table 3. The relationship between associated factors with respiratory symptoms of workers in wood furniture factory (Multivariate analysis) $(n=511)$

\begin{tabular}{|c|c|c|c|c|c|c|}
\hline \multirow[t]{2}{*}{ Factors } & \multirow[t]{2}{*}{$\mathbf{N}$} & \multirow{2}{*}{$\begin{array}{l}\text { Respiratory } \\
\text { symptoms } \\
(\%)\end{array}$} & \multicolumn{2}{|c|}{ Unadjusted } & \multicolumn{2}{|c|}{ Adjusted* } \\
\hline & & & OR & $95 \% \mathrm{Cl}$ & OR & $95 \% \mathrm{Cl}$ \\
\hline \multicolumn{7}{|c|}{ Wearing mask while working } \\
\hline Always & 427 & 27.40 & 1 & & 1 & \\
\hline Not always & 84 & 42.86 & 1.98 & $\begin{array}{l}1.22 \text { to } \\
3.21\end{array}$ & 2.26 & $\begin{array}{l}1.37 \text { to } \\
3.72\end{array}$ \\
\hline \multicolumn{7}{|c|}{ Softwood exposure } \\
\hline Not contact & 75 & 20.00 & 1 & 1 & 1 & \\
\hline Contact & 436 & 31.65 & 1.85 & $\begin{array}{l}1.02 \text { to } \\
3.38\end{array}$ & 1.97 & $\begin{array}{l}1.06 \text { to } \\
3.64\end{array}$ \\
\hline \multicolumn{7}{|c|}{ Knowledge on dust prevention } \\
\hline High level & 241 & 24.07 & 1 & & 1 & \\
\hline $\begin{array}{l}\text { Low to me- } \\
\text { dium level }\end{array}$ & 270 & 35.19 & 1.71 & $\begin{array}{l}1.16 \text { to } \\
2.52\end{array}$ & 1.83 & $\begin{array}{l}1.23 \text { to } \\
2.73\end{array}$ \\
\hline $\begin{array}{l}{ }^{*} \text { Adjusted OR } \\
\text { smoking varia }\end{array}$ & $\begin{array}{l}\text { when } \\
\text { les }\end{array}$ & control of sex, & ge, du & ation of & osure & \\
\hline
\end{tabular}

\section{DISCUSSION}

The results indicated that the majority of workers in wood furniture factory were in an operational division, has been working in the present factory for more than 5 years, working for 6 days a week ( $84.15 \%$ ) with 8 average working hours a day. These findings were concordant with the study of Anamai Thetkathuek and Tanongsak Yingratanasuk that reported $92.30 \%$ of wooden furniture factory in Eastern part of Thailand with the average working hours of 8 hours a day and the Study of Kathawut Deepreecha reported $96.60 \%$ of the workers working more than 6 hours a day. ${ }^{15,16}$ This may be explained by the fact that every organization has to follow the Labour Protection Act B.E. 2541 Chapter 2, Section 23 concerning the normal working hour, for not more than 8 hours a day. ${ }^{17}$ The prevalence of respiratory symptoms among workers in wood furniture factory was $29.94 \%$, the highest reported respiratory symptom was coughing (18.79\%), followed by having sputum and sneezing (15.66\% and $15.07 \%$ respectively). The scientific evidence indicated that when dust enter the respiratory tract, it could irritate the mucous membrane which lead to acute respiratory symptoms such as nose-itching, throat irritation, coughing, sneezing, sputum, ${ }^{18}$ stuffy/running nose. ${ }^{19}$ The study indicated that majority of the workers in wood furniture factory had high level of knowledge and attitude of dust prevention, whereas the overall dust preventive behaviors was at middle level. Individual dust preventive behaviors involved equipment's such as mask which might not available or the workers might not like wearing it especially among those who do not aware of its benefits. This was confirmed by the multivariate analysis results indicated the relationships between not wearing mask while working, low level of knowledge about dust and dust protection, and soft dust exposure with respiratory systems. Factors significantly associated with respiratory symptoms of workers in wood furniture factory were not wearing mask while working ( $p$-value $=0.001$ ), low level of knowledge about dust and dust protection ( $p$-value $=0.003$ ), and soft dust exposure ( $p$-value=0.030). The woods mostly used in the wood furniture factory were softwood. The study indicated that $85.32 \%$ of workers exposed to softwood dust which its particle was larger than 10 micron, therefore when it entered the upper respiratory tract, ${ }^{20}$ it could cause the respiratory symptoms such as coughing, sputum, sneezing, breathless, shortness of breath. The recommendations to preventing and solving respiratory tract problems among wood furniture manufacturing factory workers should concentrated on reducing dust concentration in the working environment and reduced individual workers exposure to dust. Therefore appropriate preventive measures should be: 1) dust reduction by improving air ventilation in the factory, adequately install and operate dust collectors, cleaning the workplaces and annually air quality monitoring 2) Improve preventive behaviors of the workers by strictly wearing mask when on duty, regularly cleaning their bodies, stop smoking, annual physical checkup and establish responsible body to look after the whole system.

\section{CONCLUSION}

The results of this study showed that wood dust induced respiratory symptoms in $30 \%$ of the workers in wood furniture factory. The significant factors associated with respiratory symptoms of workers were not wearing mask while working, low level of knowledge about dust and dust protection, and soft dust exposure. So that, the raising awareness for using personal protective equipment during work will help them to prevent from respiratory track problems. Furthermore, the periodic health examination of the workers and improve the working environment with assured quality will reduce the burdens. In addition, it 
would be better to conduct future studies which focus on pulmonary function of workers in wood furniture factory and factors associated with decrease the pulmonary function.

\section{Limitation}

One important limitation of this study is that it relies on a cross sectional design that does not permit causal inferences from the observed relationships. The findings should therefore be seen as provisional ones that provide a starting point for further research, including cohort studies that are better able to identify causal factors that are

\section{REFERENCES}

1. Driscoll T, Hogan A, Kearney G, Kyaw-Myint S. Occupational exposures in Australian nurse [Internet]. Methodology Report 2007 [cited 2013 Apr 11]. Available from: http://www.Sydney.edu.ac/medicine/ people/academics/profiles/time.

2. World Health Organization. Protection of the Human Environment Geneva. Occupational airborne particulates [Internet]. Environmental burden of disease series 2004 [cited 2013 Jan 20]. Available from: http://www.who.int/Quantifying_ehimpacts/publications/en/ebd7. pdf.

3. Bakerly N, Moore VC, Vellore AD. Fifteen-year trends in occupational asthma: data from the Shield surveillance scheme. Occup Med (Lond) 2008; 58:169-74.

4. Nicholas $H$, Yvonne $M$, Brooke T. Asbestos, lung cancers, and mesotheliomas from molecular approaches to targeting tumor survival pathways. Am J Respir Cell MolBiol 2010; 42:133-9.

5. Pelucchi C, Pira E, Piolatto G, Coggiola M, Carta P, La Vecchia C. Occupational silica exposure and lung cancer risk: a review of epidemiological studies 1996-2005. Ann Oncol 2006; 17:1039-50.

6. Bureau of Epidemiology, Ministry of Public Health. Occupational respiratory [Internet]. Annual Epidemiological Surveillance (Report 2007 ISSN 0857-6521.2011) [cited 2011 Oct 10]. Available from: http://epid. moph.go.th.

7. Rosenberg C, Liukkonen T, Kallas-Tarpila T, Ruonakangas A, Ranta R, Nurminen $\mathrm{M}$, et al. Monoterpene and wood dust exposures: Workrelated symptoms among Finnish sawmill workers. Am J Ind Med 2002; 41:38-53.

8. Schlunssen V, Schaumburg I, Andersen NT, Sigsgaard T, Pedersen OF. Nasal patency is related to dust exposure in woodworkers. Occup Environ Med 2002; 9:23-9.8 ric-Juric, T.Neil SE. Chronic Respiratory Symptoms in Croatian Adriatic Island Metapopulations. Croat Med J 2006; 47:627-34.

9. Susanha Y, Sujitra T. Self-care health behaviors among woodcarving workers. Nursing Journal 2007; 34:58-9. associated with respiratory symptoms of wood furniture manufacturing factory workers.

\section{ACKNOWLEDGMENTS}

The author is grateful to all contributors to this research especially the worker in wooden furniture factory who participated in this study. I would also like to thank The Research and Training Centre for Enhancing the Quality of Life of Working Age People (REQW), Faculty of Nursing, Khon Kaen University, Thailand for financial support for this research.

10. Hsieh FY, Bloch DA, Larsen MD. A simple method of sample size calculation for linear and logistic regression. Stat Med 1998; 17: 1623-34.

11. The Association of Occupational and Environmental Diseases of Thailand. Guideline for standardization and interpretation of pulmonary function test by spirometer in occupational health setting. Bangkok: Parbpim printing; 2014. 80 p.

12. American Thoracic Society. A modified version of the American thoracic society division of lung disease questionnaire [Internet] 1978 [cited 2013 Jan 26]. Available from: http://www.thoracic.org/ statements /resources/archive/rrdquacer.pdf.

13. Thetkathuek A, Yingratanasuk T, Thepaksorn P, Saowakhontha S. Rubber wood dust and lung function among Thai furniture factory workers. Int J Occup Environ Health. 2010; 16:69-74.

14. Kathawut D. Prevalence rate and associated factors of work-related respiratory diseases among wood workers at Wang-Numyen cooperation Sa Kaeo province. Master Science (Occupational Medicine). Graduate School. Chulalongkorn University. Bangkok (Thailand). 2004. 23 p.

15. Ministry of Labour and Social Welfare. Labour protection [Internet] 2008 [cited 2013 Jan 24]. Available from: http://www.mol.go.th/ sites/default/files/images/jpg/01.pdf.

16. Milanowski J, Gora A, Skorska C, Krysinska-Traczyk E, Mackiewicz B, Sitkowska J, et al. Work-related symptoms among furniture factory workers in Lublin region (Eastern Poland). Ann Agric Environ Med 2002; 9:99-103.

17. Osman E, Pala K. Occupational exposure to wood dust and health effect on the respiratory system in minor industrial estate in Bursa/ Turkey. Int J Occup Med Environ Health 2009; 22:43-50.

18. Ministry of Natural Resource and Environment [Internet]. Project (draft) standard dust particles smaller than 2.5 microns; 2002 [cited 2012 Oct 1]. Available from: http://www.aqnis. 